\title{
Effect of Operational Parameters on Draft and Power Requirement of Rigid and Spring Cultivator Tines
}

\author{
T. N. Aruna*", G. S. Tiwari and Ajay Kumar Sharma
}

Department of Farm Machinery and Power Engineering, College of Technology and Engineering, Maharana Pratap University of Agriculture and Technology, Udaipur

(Rajasthan)-313001, India

*Corresponding author

\section{A B S T R A C T}

\section{Keywords}

Soil bin, Rigid tine, Spring tine,

Reversible shovels, Draft requirement, Power requirement and energy management

\section{Article Info}

Accepted:

18 August 2020

Available Online:

10 September 2020
Energy management in farm operations is significant factor in agricultural productivity. Tillage is an energy-intensive farm operation that consumes about 40 per cent of the total energy input needed to produce crops. Data on draft and power requirements of tillage equipment is a significant factor in the selection of appropriate implement for a specific agricultural operation. As the power unit represents a significant capital outlay, it is important to have awareness of the draft and power requirement when making decisions on machinery management. The experiment was conducted in indoor soil bin in order to investigate the effect of operational parameters on draft and power requirement of selected tool. The experiments were performed by selecting locally available rigid and spring cultivator tines with reversible shovels at depth of operations of $0.08,0.10,0.12$ and 0.14 $\mathrm{m}$ and forward speeds of $0.97,1.25$ and $1.53 \mathrm{~m} / \mathrm{s}$ at a moisture content of about $9-10$ per cent and cone index of about $1060-1160 \mathrm{kPa}$. The draft and power requirement of both rigid and spring cultivator tines was directly related with speed and depth of operation. The draft and power requirements were found increased with increase in speed and depth of operation. The spring tine resulted minimum draft and power requirement $(0.39 \mathrm{k} \mathrm{N}$ and $0.5 \mathrm{~kW})$ of 10.26 per cent and 10 per cent than the rigid tine $(0.43 \mathrm{kN}$ and $0.55 \mathrm{~kW})$ respectively. In order to achieve a better energy management of a tool, spring cultivator tine found more suitable compared to rigid cultivator tine.

\section{Introduction}

Agriculture plays a significant role in the development of the nation, with around 54.6 per cent of the overall population engaged in agriculture and related activities. Currently, Indian agriculture is rising at an average annual compound growth rate of 2.8 per cent. Approximately half of the population still relies on agriculture as their main source of income and is a source of raw material for a wide number of sectors. It is therefore important to accelerate the growth of agricultural production not only to achieve an overall GDP and meet the increasing demand for food, but also to increase the incomes of those dependent on agriculture and thereby to ensure inclusiveness in our society. 
To increase agricultural productivity against the backdrop of limited resources and climate change, a sustainable agricultural approach is required (Jyoti et al., 2019). Farm machinery is a key driver of agricultural productivity. The motivation to mechanize farming activities is influenced primarily by a desire to increase food security for a family, increase household income or improve quality of life (Kepner et al., 1987).

The agricultural mechanization sector is significantly influenced by farm machinery and the methodology associated with its use (Oduma et al., 2019). Indian agriculture has seen exponential growth in the mechanization of farms (Verma and Guru, 2014). Mechanization leads to a timeliness that also increases productivity and income in turn. The country witnessed phenomenal growth in mechanization by rising food grain productivity from $0.63 \mathrm{t}$ /ha in $1965-66$ to 2.11 t/ha in 2013-14, helped the country transition from poverty to self-sufficiency in food grains (Anonymous, 2018).

Cultivator is a mechanical implement for breaking up the soil and uprooting weeds (Raut et al., 2014). A cultivator is any of many types of farm implements that are used for secondary tillage. One meaning of the term refers to frames with teeth (also called shanks) that perforate the soil as they are dragged linearly across it. Cultivators stir and pulverize the soil, either before planting to aerate the soil and prepare a smooth, loose seedbed or after the crop begins growing to kill weeds (Desai, 2012).

Cultivator is an implement, even though it is equipped for secondary tillage operation, the Indian farmers often use this for primary tillage. There are various types of tractor operated cultivators available in India, namely rigid tine cultivators and spring tine cultivators. Bureau of Indian Standard (BIS) provided standards for cultivators but commercial agricultural machinery manufacturers design on trial and error basis without understanding the concept of optimization, which in turn leads to unnecessary design and cost (Badegaonkar et al., 2010), it also affects equipment performance, leading to excessive operating costs and in turn being a burden on farmers.

In Indian condition farmers select the implement based on their previous experience and also based on cost without awareness of implement performance characteristics such as draft, power requirement, soil pulverization etc. since soil-tool interaction is a complex subject and it is difficult for farmers to understand. Data on draft and power requirements of tillage equipment is a significant factor in the selection of appropriate implement for a specific agricultural operation.

Farm managers and consultants use this to accurately decide the appropriate size of the tractor needed for a given farm operation (AlJanobi and Suhaibani, 1998). As the power unit represents a significant capital outlay, it is important to have awareness of the draft requirement when making decisions on machinery management.

Decisions to be used in future energy management of agricultural machinery also need a draft requirement. Significant design criteria for every kind of agricultural machine are optimal energy use (Mielke et al., 2004). The draft requirement for tilling tools as a function of operating speed and depth is an important criterion for the evaluation of tillage tools in field and/or laboratory conditions (Deshpande et al., 2015). The effect of speed and depth of operation on draft and power requirement of implements depends on the soil type and the type of implement. It has been widely reported that 
the draft forces and power requirement of implement increase significantly and linearly with speed and depth of operation (Sapkale, 2008). Tractive performance of tractors has been a challenging problem for many engineers. The great difference in energy data shows, significant energy savings can be achieved by selecting an energy efficient tillage (Askari and Smail, 2013).

Studying and providing possible information on the performance characteristics of the implements is very necessary in order to reduce the energy requirement, time and drudgery needed for agricultural operations and also to improve productivity. In view of this, the study was undertaken to investigate the impact of operational parameters on draft and power requirement of spring and rigid cultivator tines and compare their performance characteristics.

\section{Materials and Methods}

An experiment was conducted in indoor soil bin which was available in department of Farm Machinery and power Engineering, C.T.A.E., Udaipur. Experimental setup consists of an indoor soil bin, a power transmission unit, a control panel, a tool trolley and a soil processing trolley. Soil bin was filled with sandy soil and a soil moisture content of about 9-10 per cent and a soil cone index of $1060-1160 \mathrm{kPa}$ was maintained throughout the experiment. A $1000 \mathrm{~mm} \times 306$ $\mathrm{mm}$ tool frame with sliding bars was fabricated by MS square section to test selected cultivator tines with reversible shovel in soil bin.

An arrangement was made to fix the load cell between the main frame and the tool clamp on the sliding bar of tool frame. By adjusting the height of the clamped tine, the desired operating depth was maintained (Table 1 and 2).

\section{Selection of experimental parameters}

Experimental plan is given in Table 1.

\section{Selection of cultivator tines and shovels}

The survey had been conducted for the selection of locally available rigid and spring cultivator tines and reversible shovels. The selection was made based on the availability and usability by the farmers for various agricultural operations.

\section{Depth of operation}

The experiments were performed within the range of $0.04 \mathrm{~m}$ to $0.20 \mathrm{~m}$ depth of operation based on the use of cultivators with reversible shovels for various agricultural practices such as tillage, sowing and intercultural operation (Sapkale et al., 2011). Keeping this and other previous research works by Yadav et al., 2015, Salaunke et al., 2016 the operating depth was selected as $0.08,0.10,0.12$ and $0.14 \mathrm{~m}$.

\section{Speed of operation}

The average speed of travel recommended by BIS (IS: 9164-1979) for a tractor cultivator is about $6 \mathrm{~km} / \mathrm{h}$. Usually for different operations the tractor-drawn cultivator is operated at a forward speed of approximately $0.94-1.81 \mathrm{~m} / \mathrm{s}$ (Sapkale et al., 2011). Previous studies by Sapkale et al., 2010, Salaunke et al., 2015 were also considered during operating speed selection and performed at speeds of 0.97 , 1.25 and $1.53 \mathrm{~m} / \mathrm{s}$. Keeping this in mind the forward speed of the tool trolley operated by the variable speed motor through the control panel and determined using the following formula:

$\mathrm{S}=\frac{\mathrm{d}}{\mathrm{t}}$ 
Where,

$\mathrm{S}=$ Forward speed of tool trolley, $\mathrm{m} / \mathrm{s}$

$\mathrm{d}=$ Distance travelled, $\mathrm{m}$

$\mathrm{t}=$ Time required, $\mathrm{sec}$

Parameters measured during the
experiment

\section{Moisture content}

The soil moisture content was measured using the digital moisture meter. It was maintained within the range of 9-10 per cent throughout the experiment.

\section{Soil cone index}

Soil cone index indicates the resistance offered by the soil for disruption against the tool. The soil cone index was measured from zero to $15 \mathrm{~cm}$ depth of the soil using a Field Scout digital cone penetrometer by inserting it into the soil surface at a rate of $25-30 \mathrm{~mm} / \mathrm{s}$. It was maintained of about $1060-1160 \mathrm{kPa}$ throughout the experiments.

\section{Draft requirement}

Draft is the force which requires to pullthe implement (Mehta et al., 2014). Draft requirement was measured by using pre calibrated load cell with digital indicator.

\section{Power requirement}

The power requirement by the implement is very important from the point of view of the design and the user. Power requirement for the operation of the implement was calculated by the following formula:

$$
\text { Power requirement, } \mathrm{kW}=\operatorname{draft}(\mathrm{kN}) \times \operatorname{speed}(\mathrm{m} / \mathrm{s})
$$

\section{Statistical analysis}

The data from experiments were analysed using the CRD method. With the help of this design, the ANOVA table was drawn up to check the significant effect of the operational parameters on the draft and power requirements. In addition, a regression analysis was conducted to predict the relationship between the speed with both draft and power requirement.

\section{Results and Discussion}

Effect of tine, shovel, speed and depth of operation on draft requirement

Figures 3 and 4 indicate that the draft requirement increased with increase in depth and forward speed for both rigid and spring cultivator tines. Rigid tine required higher draft of 10.26 per cent $(0.43 \mathrm{kN})$ than the draft of requirement of spring tine $(0.39 \mathrm{kN})$. The shovel 1 at both rigid and spring cultivator tines required maximum draft than shovel 2 and shovel 3. In rigid tine, shovel $1(0.49 \mathrm{kN})$ required draft of 16.66 per cent higher than shovel $2(0.42 \mathrm{kN})$ and 32.43 per cent higher than shovel $3(0.37 \mathrm{kN})$, while in spring tine, draft requirement of shovel 1 $(0.45 \mathrm{kN})$ was found 18.42 per cent and 36.36 per cent higher than shovel 2 and shovel 3 $(0.38 \mathrm{kN}$ and $0.33 \mathrm{kN})$.

The draft requirement of the tools was influenced by both the depth and speed of operation. The draft requirement of the tool increased with an increase in depth, it was greater at a depth beyond $0.12 \mathrm{~m}$. This may be due to volume of the soil handle by tool increased with an increase in depth of operation, thereby it increases amount of force required to pull the soil. Similar findings have been reported by Deshpande (2008).

The draft requirement was found to be higher at higher operating speed $(1.53 \mathrm{~m} / \mathrm{s})$ for both tines. This may be due to the acceleration forces of the soil on the soil engaging surface of the tool. This soil acceleration force 
enhances the normal load on the working tool by increasing the frictional resistance and also by increasing the kinetic energy of the soil. At lower depth $(0.08 \mathrm{~m})$ the draft requirement was negligibly changed due to the minimum amount of soil to be handled. Also shovel 3 developed least draft than all other shovels at both rigid and spring tines, this may be because of geometrical parameters of the tool. ANOVA table (Table 2) shows that draft requirement is significantly affected by tine, shovel, speed, depth of operation and their interactions at 5 per cent level of significance.

\section{Effect of tine, shovel, speed and depth of operation on power requirement}

The figures 5 and 6 indicate that the power requirement for both tines increased with increase in speed and depth of operation. The slope indicates that the increase in speed affects the power requirement more than the operating depth. It may be because of the acceleration forces of the tool that develop at higher speed of operation. Similar findings have been reported by Sapkale (2008).

Rigid tine $(0.55 \mathrm{~kW})$ required higher power of 10 per cent than spring tine $(0.5 \mathrm{~kW})$ within the test range of all speed and depth of operation. This may be due to movement of the rigid tine which resulted higher draft requirement. In rigid tine, shovel $1(0.63 \mathrm{~kW})$ required higher power than the shovel 2 and shovel 3 of about 16.66 per cent and 34.04 per cent $(0.54 \mathrm{~kW}$ and $0.49 \mathrm{~kW})$ respectively. Also shovel $1(0.58 \mathrm{~kW})$ at spring tine produced higher than the shovel 2 of 18.36 per cent $(0.49 \mathrm{~kW})$ and shovel 3 of 38.08 per cent $(0.42 \mathrm{~kW})$.

Shovel 3 of both the tines attributed to less power requirement among all other shovels, this is because of impact of draft and geometric parameters of tool.

The ANOVA table (Table 3) indicates that, power requirement is significantly affected by tine, shovel, speed, depth and their interaction at 5 per cent level of significance.

In order to assess the relation between the power requirement and the speed, a linear regression analysis was performed for the shovels of both tines at different depths.

$\mathrm{PR}=\mathrm{m}_{3} \mathrm{~s}+\mathrm{C}_{3} \ldots$

Where, $\mathrm{PR}=$ power requirement

$\mathrm{m}_{3}=$ Slope of line

$\mathrm{s}=$ speed of operation, $\mathrm{m} / \mathrm{s}$

$\mathrm{C}_{3}=$ regression constant

The $\mathrm{R}^{2}$ value indicates that the power requirement values are reasonably well predicted by the relation (Table 4 ).

Table.1 Experimental plan

\begin{tabular}{|c|c|c|c|}
\hline Sl.no & Experimental parameters & Levels & Particulars \\
\hline \multicolumn{4}{|c|}{ Independent parameters } \\
\hline 1. & Cultivator tines & 2 & $\mathrm{CT}_{1}$ and $\mathrm{CT}_{2}$ \\
\hline 2. & Reversible shovels & 3 & $\mathrm{Sh}_{1}, \mathrm{Sh}_{2}$ and $\mathrm{Sh}_{3}$ \\
\hline 1. & Speed, $\mathrm{m} / \mathrm{s}$ & 3 & $0.97,1.25$ and 1.53 \\
\hline 2. & Depth, m & 4 & $0.08,0.10,0.12$ and 0.14 \\
\hline \multicolumn{4}{|c|}{ Dependent parameters } \\
\hline 1. & Draft, $\mathrm{kN}$ & & \\
\hline 2. & Power requirement, $\mathrm{kW}$ & & \\
\hline
\end{tabular}


Table.2 Analysis of variance for tine, shovel, speed and depth of operation on draft requirement

\begin{tabular}{|l|l|l|l|c|}
\hline \multicolumn{1}{|c|}{ Source } & df & $\begin{array}{c}\text { Sum of } \\
\text { square }\end{array}$ & $\begin{array}{c}\text { Mean } \\
\text { square }\end{array}$ & F value \\
\hline Tine & 1 & 0.086 & 0.086 & $4551.805^{* *}$ \\
\hline Shovel & 2 & 0.552 & 0.276 & $14550.610^{* *}$ \\
\hline Depth & 3 & 5.684 & 1.895 & $99816.260 * *$ \\
\hline Speed & 2 & 0.888 & 0.444 & $23382.902 * *$ \\
\hline Tine $\times$ shovel & 2 & 0.000 & 0.000 & $9.732^{* *}$ \\
\hline Tine $\times$ depth & 3 & 0.008 & 0.003 & $142.114^{* *}$ \\
\hline Tine $\times$ speed & 2 & 0.001 & 0.000 & $16.463 * *$ \\
\hline Shovel $\times$ depth & 6 & 0.196 & 0.033 & $1721.211^{* *}$ \\
\hline Shovel $\times$ speed & 4 & 0.009 & 0.002 & $113.732^{* *}$ \\
\hline Depth $\times$ speed & 6 & 0.102 & 0.017 & $898.089 * *$ \\
\hline Tine $\times$ shovel $\times$ depth & 6 & 0.003 & 0.000 & $25.211^{* *}$ \\
\hline Tine $\times$ shovel $\times$ speed & 4 & 0.002 & 0.000 & $23.341^{* *}$ \\
\hline Tine $\times$ depth $\times$ speed & 6 & 0.002 & 0.000 & $13.407 * *$ \\
\hline Shovel $\times$ depth $\times$ speed & 12 & 0.017 & 0.001 & $72.480 * *$ \\
\hline Tine $\times$ shovel $\times$ depth $\times$ speed & 12 & 0.002 & 0.000 & $8.528^{* *}$ \\
\hline Error & 144 & 0.003 & 0.000 & \\
\hline Total & 71 & 7.551 & 0.106 & $5603.018 * *$ \\
\hline
\end{tabular}

Table.3 Analysis of variance for tine, shovel, speed and depth of operation on power requirement

\begin{tabular}{|l|l|c|c|c|}
\hline Source & df & $\begin{array}{c}\text { Sum of } \\
\text { square }\end{array}$ & $\begin{array}{c}\text { Mean } \\
\text { square }\end{array}$ & F value \\
\hline Tine & 1 & 0.139 & 0.139 & $6528.348^{* *}$ \\
\hline Shovel & 2 & 0.902 & 0.451 & $21185.478^{* *}$ \\
\hline Depth & 3 & 9.292 & 3.097 & $145444.522^{* *}$ \\
\hline Speed & 2 & 6.517 & 3.259 & $153008.283^{* *}$ \\
\hline Tine $\times$ shovel & 2 & 0.000 & 0.000 & $10.783^{* *}$ \\
\hline Tine $\times$ depth & 3 & 0.014 & 0.005 & $218.203^{* *}$ \\
\hline Tine $\times$ speed & 2 & 0.010 & 0.005 & $223.848^{*}$ \\
\hline Shovel $\times$ depth & 6 & 0.334 & 0.056 & $2616.957^{* *}$ \\
\hline Shovel $\times$ speed & 4 & 0.072 & 0.018 & $842.707^{*}$ \\
\hline Depth $\times$ speed & 6 & 0.895 & 0.149 & $7004.196^{* *}$ \\
\hline Tine $\times$ shovel $\times$ depth & 6 & 0.004 & 0.001 & $32.116^{* *}$ \\
\hline Tine $\times$ shovel $\times$ speed & 4 & 0.002 & 0.001 & $25.946^{* *}$ \\
\hline Tine $\times$ depth $\times$ speed & 6 & 0.004 & 0.001 & $34.486^{* *}$ \\
\hline Shovel $\times$ depth $\times$ speed & 12 & 0.065 & 0.005 & $253.663^{* *}$ \\
\hline Tine $\times$ shovel $\times$ depth $\times$ speed & 12 & 0.004 & 0.000 & $16.236^{* *}$ \\
\hline Error & 144 & 0.003 & 0.000 & \\
\hline Total & 71 & 18.255 & 0.257 & $12073.426^{* *}$ \\
\hline
\end{tabular}


Table.4 Linear regression constants for predicting power requirement at different depths

\begin{tabular}{|c|c|c|c|c|c|c|c|c|c|}
\hline \multicolumn{10}{|c|}{ Tine $1\left(\mathbf{C T}_{1}\right)$} \\
\hline \multirow[t]{3}{*}{ Depth, m } & \multicolumn{9}{|c|}{ Shovel } \\
\hline & \multicolumn{3}{|c|}{$\mathbf{S h}_{1}$} & \multicolumn{3}{|c|}{$\mathbf{S h}_{2}$} & \multicolumn{3}{|c|}{$\mathrm{Sh}_{3}$} \\
\hline & m & $\mathbf{C}_{1}$ & $\mathbf{R}^{2}$ & $\mathbf{m}$ & $\mathbf{C}_{1}$ & $\mathbf{R}^{2}$ & m & $\mathbf{C}_{1}$ & $\mathbf{R}^{2}$ \\
\hline 0.08 & 0.446 & 0.239 & 0.992 & 0.463 & 0.293 & 0.991 & 0.388 & 0.239 & 0.990 \\
\hline 0.10 & 0.660 & 0.339 & 0.999 & 0.613 & 0.345 & 0.994 & 0.566 & 0.325 & 0.978 \\
\hline 0.12 & 0.978 & 0.526 & 0.999 & 0.848 & 0.452 & 0.995 & 0.811 & 0.458 & 0.989 \\
\hline 0.14 & 1.485 & 0.842 & 0.998 & 1.219 & 0.663 & 0.995 & 0.945 & 0.485 & 0.989 \\
\hline \multicolumn{10}{|c|}{ Tine $2\left(\mathrm{CT}_{2}\right)$} \\
\hline 0.08 & 0.375 & 0.188 & 0.993 & 0.432 & 0.293 & 0.990 & 0.359 & 0.236 & 0.999 \\
\hline 0.10 & 0.616 & 0.322 & 0.991 & 0.644 & 0.423 & 0.995 & 0.546 & 0.344 & 0.998 \\
\hline 0.12 & 0.867 & 0.451 & 0.995 & 0.837 & 0.479 & 0.991 & 0.727 & 0.400 & 0.993 \\
\hline 0.14 & 0.998 & 0.737 & 0.999 & 1.078 & 0.584 & 0.994 & 0.895 & 0.488 & 0.984 \\
\hline
\end{tabular}

Fig.1 Selected cultivator tines

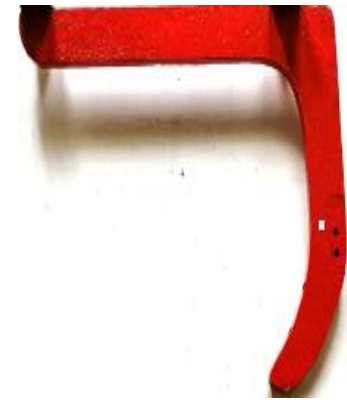

a. Rigid tine

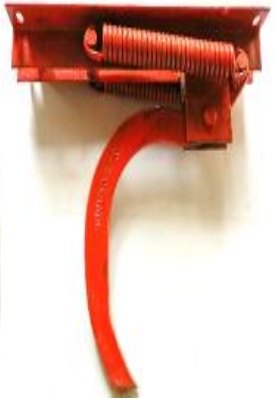

b. Spring tine

Fig.2 Selected reversible shovels

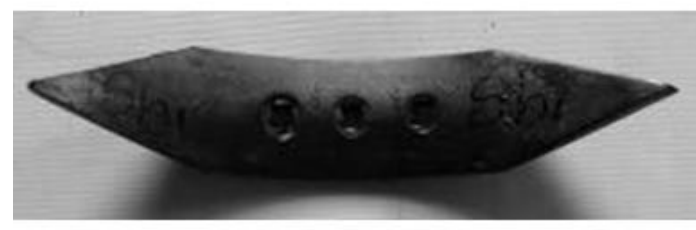

a. Shovel 1

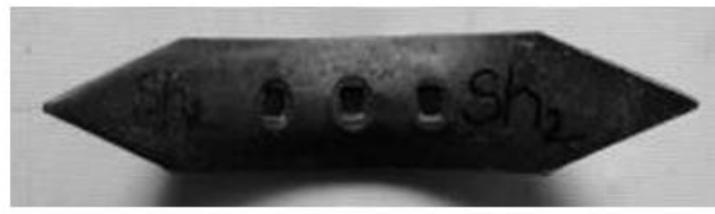

b. Shovel 2

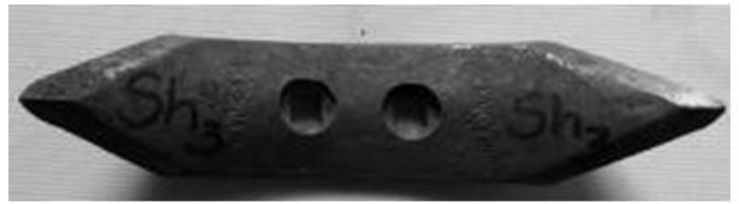


Fig.3 Effect of speed on draft requirement of different shovels of rigid tine at different depths

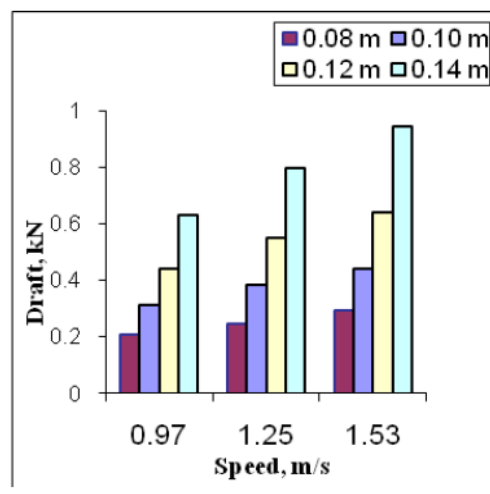

Shovel 1

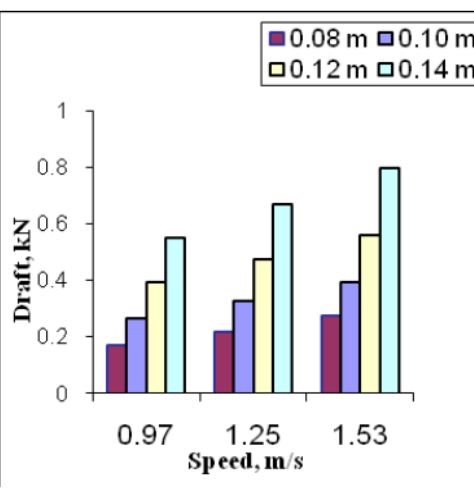

Shovel 2

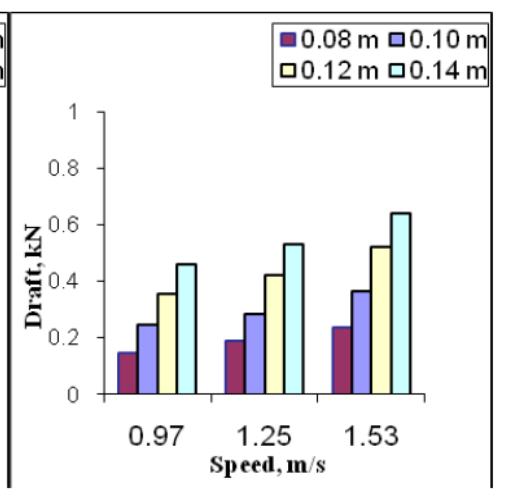

Shovel 3

Fig.4 Effect of speed on draft requirement of different shovels of spring tine at different depths

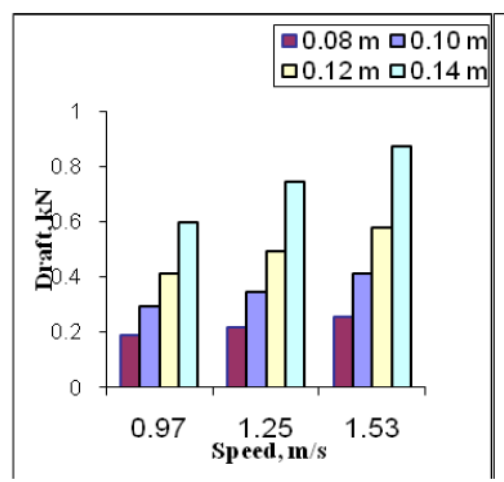

Shovel 1

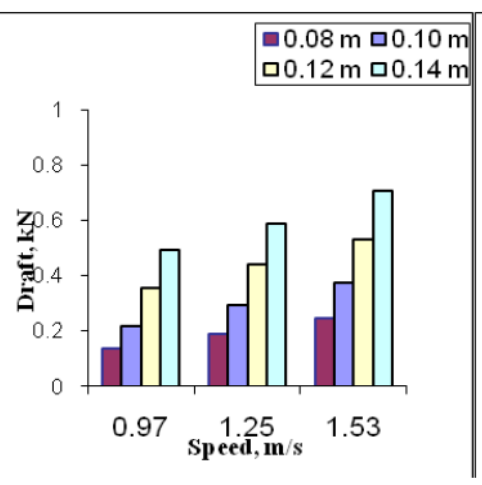

Shovel 2 $\square 0.08 \mathrm{~m} \square 0.10 \mathrm{~m}$ $\square 0.12 \mathrm{~m} \square 0.14 \mathrm{~m}$

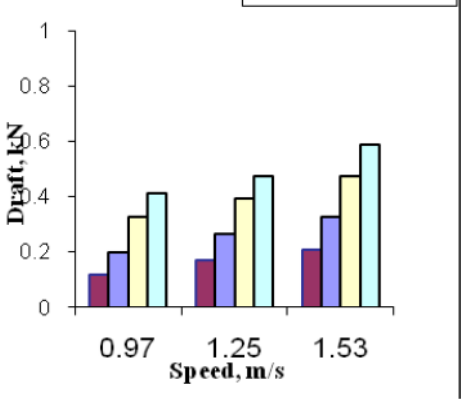

Shovel 3

Fig.5 Effect of speed on power requirement of different shovels of rigid tine at different depths

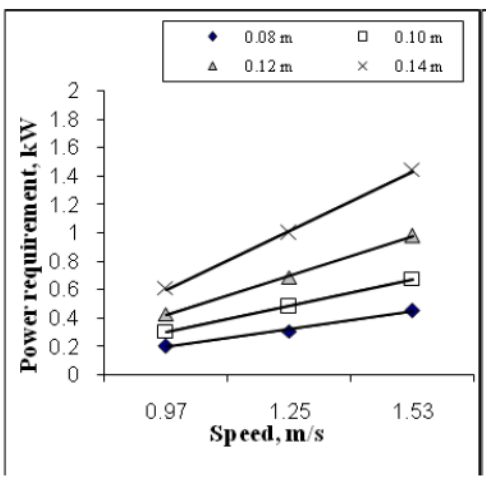

Shovel 1

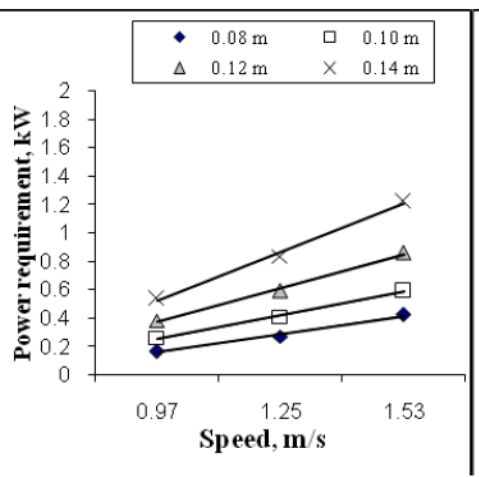

Shovel 2

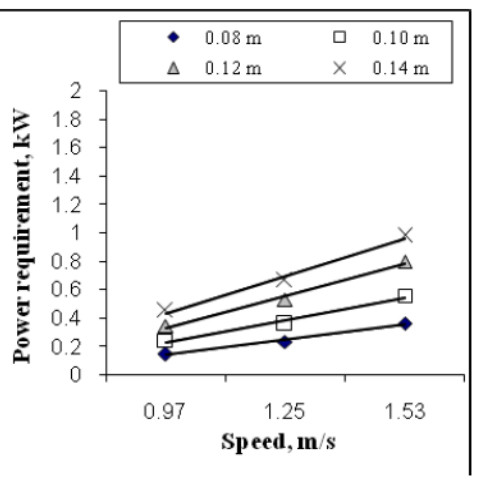

Shovel 3 
Fig.6 Effect of speed on power requirement of different shovels of spring tine at different depths

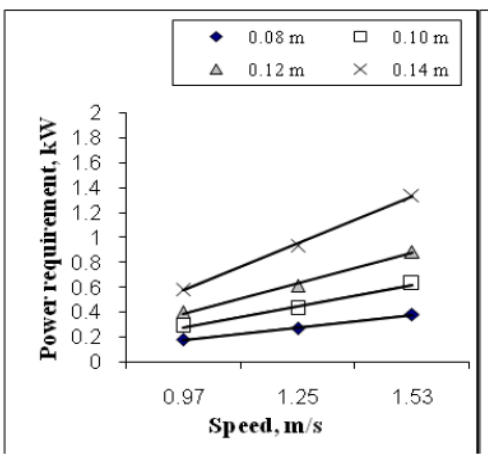

Shovel 1

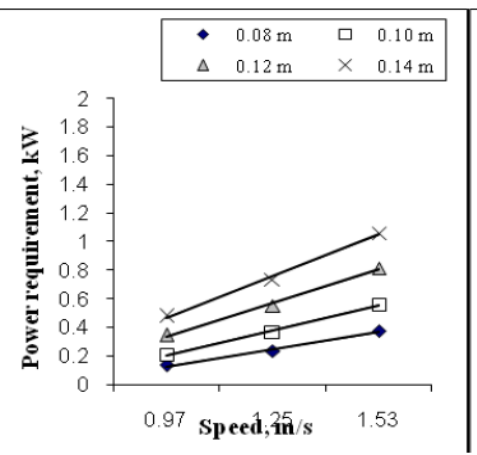

Shovel 2

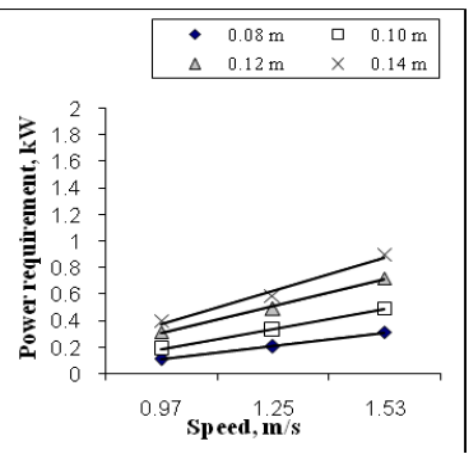

Shovel 3

Fig.7 Comparative performance characteristics of rigid and spring cultivator tine

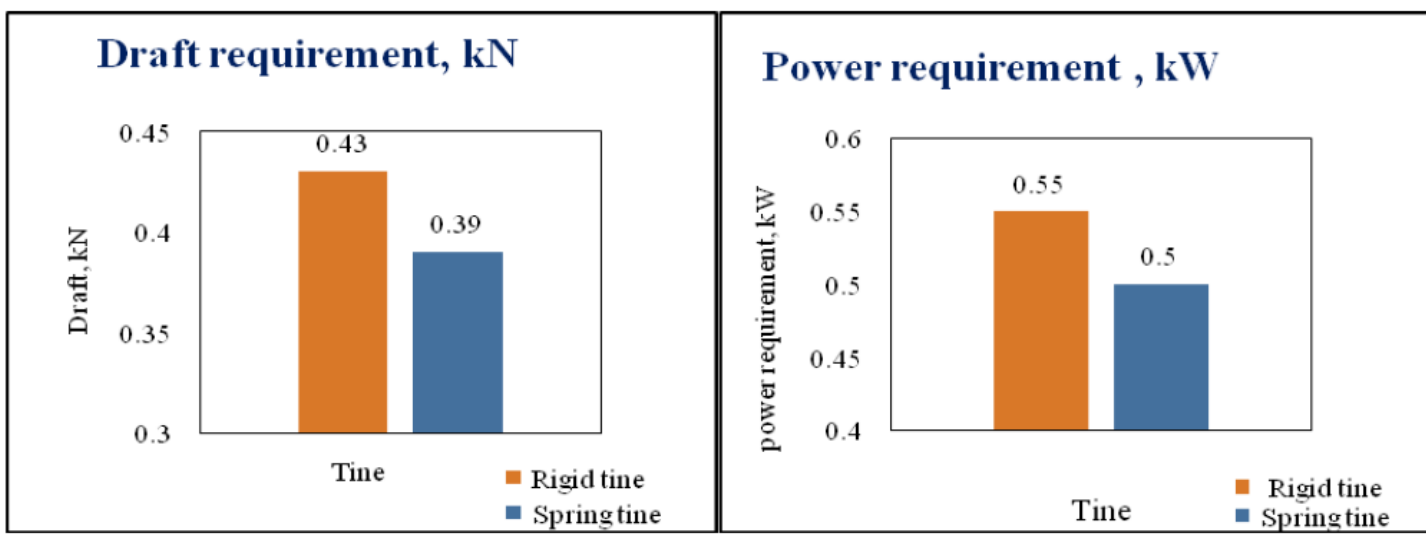

\section{Comparative performance between selected rigid and spring cultivator tines}

The comparison was made between the draft and power requirement of selected rigid and spring cultivator tines along with the selected reversible shovels at a different combination of different operating speed and depth of operations (Fig.6).

\section{Draft requirement}

The draft requirement was highly influenced by both speed and depth of operation. The rigid tine $(0.43 \mathrm{kN})$ required maximum draft of 10.26 per cent compared to spring tine $(0.39 \mathrm{kN})$. This may due to easy movement of spring tine at same depth and speed of rigid tine.

\section{Power requirement}

The power required by the tool was increased with increase in speed and depth of operations. The rigid tine $(0.55 \mathrm{kw})$ required maximum power of 10 per cent compared to spring cultivator tine $(0.5 \mathrm{~kW})$. As the speed increased power required by the tines were increased at all operating depths. It may be due to soil acceleration force at higher speed of operation.

In conclusion the selection of appropriate implements for specific agricultural operation 
is important factor in order reduce the energy requirement. In order to achieve best performance of a tool, the draft and power requirement should be minimum. The results obtained from the study shows that, spring tine required minimum draft and power requirement. Therefore, in terms of minimum energy requirement for the agricultural operations, spring cultivator tine found most suitable compared to rigid cultivator tine.

\section{Acknowledgement}

The authors would like to thank Department of Farm machinery and Power Engineering, College of Technology and Engineering, M.P.U.A.T., Udaipur, Rajasthan, India for providing all kinds of required facilities to carry out the present study. It is my proud privilege to express my devote gratitude and indebtedness to my erudite mentor Dr.G.S. Tiwari, Professor, department of Farm Machinery and Power Engineering, C.T.A.E., Udaipur for his thoughtful guidance, constant fomenting and impeccable advices throughout the course of present study, which inspired me to carry out the research work in time.

\section{References}

Alsuhaibani, S.A. and Ghalay, A.E. 2010. Effect of ploughing depth of tillage and forward speed on the performance of a medium size chisel plough operating in a sandy soil. American Journal of Agricultural and Biological Sciences, 5: 247-255.

Anonymous. 2018. Annual report. Directorate of Agriculture / Ministry of Agriculture.

Askari, M and Smail, K. 2013.Draft force inputs for primary and secondary tillage implements in a clay loam soil. World Applied Sciences Journal, 21: 17891794.

Badegaonkar, U.R., Dixit, G. and Pathak,
K.K. 2010. An experimental investigation of cultivator shank shape on draft requirement. Archives of Applied Science Research, 2:246-255.

Desai, R. 2012. E-course on Farm power and machinery.

http://ecoursesonline.iasri.res.in

Deshpande, S., Shirwal, S. and Basavaraj. 2015. Studies on operational parameters of selected tillage tools in soil bin. International Journal of Latest Trends in Engineering and Technology, 5: 1-9.

Jyoti1, B., Ram Reddy, K.V.S., Sawant, C.P., Pandirwar, A.P., Potdar, R.R. and Randhe, R.D. 2019. Predicting draft requirement of tillage implements using pull type loadcell in southern region of Andhra Pradesh, India. International Journal of Current Microbiology and Applied Sciences, 9: 606-612

Kepner, R.A., Bainer, R. and Barger, E.L. 1987. Textbook of Principle of farm machinery. Third edition. CBS publishers and distributors pvt.Ltd. New Delhi. India, pp: 3-4.

Mehta, C.R., Chandel, N.S., Senthilkumar, T. and Singh, K.K. 2014. Trends of Agricultural Mechanization in India. CSAM, Policy.

Mielke, L.N., Grisso, R.D, Bashford, L.L. and A.M., Parkhurst. 2014. Bi-level subsoiler performance using tandem shanks. Transaction of ASAE. 30: 345349.

Oduma, O., Oluka, S.I., Nwakuba, N.R. and Ntunde, D.I. 2019. Agricultural field machinery selection and utilization for improved farm operations in South-East Nigeria- A review. Agricultural Engineering, 3: 44-58

Raut, P.M., Thakre, G.V., Thakre, R.D. and Gulhane, U.D. 2014. FEM analysis of nine tine medium duty cultivator. IORD Journal of science \& Technology, 1: 5865.

Salunke, V.V. 2016. Performance evaluation 
of commercially available tractor drawn cultivator sweeps in sandy loam soil. Unpublished M. Tech. thesis submitted to Maharana Pratap University of Agriculture and Technology, Udaipur, Rajasthan.

Sapkale, P.R., Sharma, A.K., Bastewad, T.B. and Mahajan, J.B. 2011. Influence of tool shape and operating parameters on soil disruption of reversible shovels for tractor drawn cultivator in sandy loam soil. Journal of Agriculture Research Technology, 36: 108-112.

Verma, A and Guru, P.K. 2014. Development and evaluation of cultivator cum seed Drill. Article in Ecology, Environment and Conservation, 21: 1359-1364.

Yadav, B.K., Indra, M. and Panwar, S.J. 2006. Relationship between disc geometry and draft requirement. Journal of Agricultural Engineering, 43: 49-52.

\section{How to cite this article:}

Aruna, T. N., G. S. Tiwari and Ajay Kumar Sharma. 2020. Effect of Operational Parameters on Draft and Power Requirement of Rigid and Spring Cultivator Tines. Int.J.Curr.Microbiol.App.Sci. 9(09): 2488-2498. doi: https://doi.org/10.20546/ijcmas.2020.909.311 